\title{
Aliskiren Protects against Hypercholesterolemia and Oxidative Stress on Isolated Aortae in Cholesterol-Fed Rats
}

Sahar Mohamed Kamal*

Department of Pharmacology, Faculty of Medicine, Ain Shams University, Cairo, Egypt

\begin{abstract}
Background: Atherosclerosis and endothelial dysfunction are important associated disorders in the majority of hypertensive patients. Many studies are directed towards investigating any possible anti-hyperlipidemic effect with improvement of arterial compliance of newer generations of antihypertensive drugs so as to reduce the number of drugs used to treat those patients.
\end{abstract}

Aim: The present study aims to determine the effects of aliskiren, a direct renin inhibitor, on serum cholesterol and some anti-oxidant enzymes together with aortic TBARS and vasorelaxant effect of acetyl-choline (Ach) on isolated aortic rings of cholesterol-fed rats.

Methods: The duration of the study was 12 weeks. Twenty-four rats were randomly divided into 3 groups ( $\mathrm{n}=8$ rats/ group). Group (1) is control, received $0.5 \%$ carboxymethylcellulose (CMC) sodium, as a solvent of aliskiren, and fed ordinary diet. Group (2) fed $2 \%(\mathrm{w} / \mathrm{w})$ cholesterol diet + CMC sodium. Group (3) was fed with $2 \%(\mathrm{w} / \mathrm{w})$ cholesterol diet with ip daily administration of aliskiren at a dose of $5 \mathrm{mg} / \mathrm{kg}$ for 12 weeks. Systolic blood pressure (SBP) was assessed both at the beginning and at the end of every 4 weeks of the study. Serum total cholesterol, superoxide dismutase (SOD) enzyme in erythrocyte lysates, thiobarbituric acid reactive substance [TBARS] content, activities of catalase and glutathione enzymes in aortic homogenates of tested rats were measured. The thoracic aortae were removed from all tested rats to assess the vasorelaxant effect of Ach.

Results: Aliskiren-treated group (3) showed a significant improvement of all the markers in comparison with nontreated cholesterol-fed rats. SBP of treated group was maintained at levels comparable to control group (1) with marked improvement in aortic reactivity to ACh compared to group (2).

Conclusion: Aliskiren could possess an anti-hypercholestrolemic and an ability to improve aortic reactivity via an anti-oxidant effect and a reduction in lipid peroxidation in cholesterol-fed rats.

Keywords: Aliskiren; Cholesterol-fed rats; Aorta; Anti-oxidant enzymes; TBARS

\section{Introduction}

Angiotensin II [ Ang II] plays an important role as a mediator in the renin-angiotensin-aldosterone system (RAAS) and it greatly contributes to the pathogenesis of hypercholesterolemia-induced atherosclerosis [1]. It was suggested by many researchers to use angiotensin-converting enzyme (ACE) inhibitors and AT1 receptor antagonists to limit the size of atherosclerotic lesion and hence to reduce its vascular complications $[2,3]$. A possible beneficial effect could be induced by the direct renin inhibitor (DRI) drug, aliskiren, in relation to vascular reactivity in cases of hypercholesterolemia and associated oxidative stress. Yet, it is not well defined if the vascular protection induced by drugs acting on RAAS is due to the resulting inhibition of Ang II production, the inhibition of the effect of Ang II on Angiotensin receptors type 2 (AT2) or the accompanied availability of other bioactive angiotensin peptides as Ang III, Ang IV, and Ang1-7 that affect receptors other than Angiotensin receptors type 1 (AT1) [4-6]. Pharmacological researches, done on aliskiren, could provide suggested evidence about its possible action on different types of angiotensin in the pathogenesis of atherosclerosis. There is a relationship between all components of the RAAS pathway and macrophages that stimulate the transcription of mRNA and protein of all components of this pathway and at the same time have an important role in development of atherosclerotic lesions $[7,8]$. Hypercholesterolemia causes atherosclerosis partly via stimulation of AT1 receptors and partly via in-vivo infusion of Ang II $[1,9]$. Angiotensin peptides, notably Ang II, allow the formation of atherosclerotic plaques on vascular endothelial cells via damaging actions on endothelium in the presence of active macrophages [9].
Aliskiren is the prototype drug in a new generation of orally direct renin inhibitors and it is used in the treatment of hypertension. It reduces plasma renin activity [PRA] and Ang II levels [10]. Further investigations are needed to be done on aliskiren to identify its effects on the serum cholesterol level and free radicals production. These studies could determine an important possible role of this drug in the control of the pathogenesis of atherosclerosis. High serum cholesterol level is markedly associated with a greater incidence of atherosclerosis [11]. The increase in the level of "bad lipoprotein"ie low-density lipoprotein "LDL"or the reduction in the level of "good lipoprotein" high-density lipoprotein "HDL" stimulates the damaging process of arterial endothelium that is considered to be the trigger of induction of atherosclerosis [11,12]. LDL are chemically modified in case of endothelial damage and stimulate the aggregation of monocytes in the vascular wall. Monocytes are converted to macrophages that engulf the modified lipoproteins and produce foam cells [13]. Free radicals abolish the function of endothelium-derived vasodilatation through

*Corresponding author: Sahar Mohamed Kamal, Department of Pharmacology, Faculty of Medicine, Ain Shams University, Cairo, Egypt, Tel: 00202-24186992. Fax: 00202-24186992; E-mail: saharkamal2003@hotmail.com

Received November 26, 2013; Accepted December 27, 2013; Published December 29, 2013

Citation: Kamal SM (2013) Aliskiren Protects against Hypercholesterolemia and Oxidative Stress on Isolated Aortae in Cholesterol-Fed Rats. J Nanomed Nanotechol S5:007. doi:10.4172/2157-7439.S5-007

Copyright: (c) 2013 Kamal SM. This is an open-access article distributed under the terms of the Creative Commons Attribution License, which permits unrestricted use, distribution, and reproduction in any medium, provided the original author and source are credited. 
inhibition of nitric oxide (NO) that is essential for the integrity of the vascular endothelium and may protect against the development of atherosclerosis [14]. The anti-oxidant enzymes as superoxide dismutase (SOD) protect NO and hence help in the maintenance of normal vascular tone via inactivation of ROS and the protection against lipid perioxidative injury of vascular endothelial cells [15].

The aim of the present study is to determine a possible protective effect of aliskiren on the aorta against hypercholesterolemia and abnormalities in its contents of anti-oxidant enzymes and impairment in its aortic reactivity to acetyl-choline $(\mathrm{ACh})$ in cholesterol-fed rats.

\section{Material and Methods}

\section{Chemicals}

Aliskiren fumarate (Novartis Pharma.co.) purchased as a white to slightly yellowish crystalline powder with a molecular weight of 609.8 , spectrophotometric assay kits for measurement of serum total cholesterol level (Boerhinger-Mannheim), and superoxide dismutase enzyme [RANSOD, by Randox Laboratories]. All other chemicals were obtained from Sigma Chemical Co. Aliskiren's powder was dissolved in $0.5 \%$ carboxymethylcellulose sodium, its solution was freshly prepared throughout the experimental study.

\section{Animals}

Twenty-four rats were randomly divided into three groups $(n=8 /$ group):

Group (1) Control group: fed with ordinary diet $+0.5 \%$ carboxymethylcellulose (CMC) sodium ip, as a solvent of aliskiren.

Group (2) Cholesterol-fed group received ip $0.5 \%$ carboxymethylcellulose (CMC) sodium

Group (3) Aliskiren-treated (5 $\mathrm{mg} / \mathrm{kg} /$ day ip) cholesterol-fed group. The drug was dissolved in $0.5 \%$ carboxymethylcellulose (CMC) sodium.

The duration of the study was 12 weeks. Dose of aliskiren was selected according to the pilot study, done before the full experimental work, showed that it produced significant $(p<0.05)$ changes in the measured parameters.

Cholesterol-fed diet of groups 2 and 3 was supplemented with $2 \%$ $(\mathrm{w} / \mathrm{w})$ cholesterol during the whole duration of the study according to Aihara et al. [16]

NB: In the pilot study done by the author, an aliskiren dissolved in $0.5 \%$ carboxymethylcellulose (CMC) sodium was administrated in the studied dose to a pilot group, fed on ordinary diet, showed no significant difference in the measured parameters of the present study compared to the control group fed on ordinary diet.

\section{Ethics}

All procedures were in accordance with the National Institute of Health's Guide for the Care and Use of Laboratory Animals, as well as the guidelines of the Animal Welfare Act.

\section{Methods}

Assessment of systolic blood pressure (SBP) changes

SBP was measured by a tail-cuff sphygmomanometer (UR-5000, Ueda Co, Ltd, Japan). For each animal an average of at least three consecutive measurements was taken to reduce variability [17].

Measurement of serum total cholesterol level:
At the end of the $12^{\text {th }}$ week, serum total cholesterol (TC) was determined for all rats using commercially available spectrophotometric assay kits (Rats were fasted for 12 hours before blood sampling).

\section{Determination of SOD enzyme level in erythrocyte lysates}

At the end of the $12^{\text {th }}$ week of the study, blood samples were collected from rats of all groups for measurement of SOD levels in erythrocyte lysates, using commercially-available colorimetric assay kits, based on an indirect xanthine-xanthine oxidase method as described by Halliwell and Chirico [18], and results were expressed in $\mathrm{IU} / \mathrm{mL}$

Measurement of activities of some anti-oxidant enzymes and TBARS in aortic homogenates

Abdominal aorta was promptly excised after the rats were dissected and were weighed and then chilled in ice-cold PBS. After being washed with PBS, tissue homogenates were prepared in a ratio of $1 \mathrm{~g}$ of wet tissue to $9 \mathrm{~mL}$ of PBS by use of a glass homogenizer. Homogenates were stored at $-40^{\circ} \mathrm{C}$ until analysis. When needed, specimens were thawed and catalase (CAT), glutathione peroxidase (GPx) enzymes and TBARS were determined as described below.

Determination of Catalase Enzyme Activity: Catalase Enzyme Activity in the aortic homogenates was assayed colorimetrically as described by Sinha [19] using dichromate-acetic acid reagent (5\% potassium dichromate and glacial acetic acid mixed in 1:3 ratio). The intensity was measured at $620 \mathrm{~nm}$ and the amount of hydrogen peroxide was calculated for the catalase activity.

Determination of Glutathione Peroxidase [GPx] Enzyme Activity: Glutathione Peroxidase [GPx] Enzyme Activity in the aortic homogenates was measured by the method described by Rotruck et al. [20]. GPx activity was assayed in the aortic tissue by being homogenized in 8 volumes of cold buffer ( $50 \mathrm{mM}$ Tris- $\mathrm{HCl}$, pH 7.5, containing $5 \mathrm{mM}$ EDTA and $1 \mathrm{mM} 2$-mercaptoethanol), next centrifuged $8500 \mathrm{xg}$ for 10 minutes at $40 \mathrm{C}$. GPx activity was determined in supernatant using BIOXYTECH GPX-340TM Assay kit produced by OXIS International, Inc., USA. The GPx assay was based on the oxidation of NADPH to $\mathrm{NADP}+$, which is accompanied by a decrease in absorbance at $340 \mathrm{~nm}$. The rate of this decrease is directly proportional to the GPx activity in the sample.

Thiobarbituric Acid-Reactive Substance (TBARS) assay of aortic homogenates [21]: $20 \mu \mathrm{L}$ aortic homogenate was added to $2 \mathrm{~mL} 40$ $\mathrm{mmol} / \mathrm{L} \mathrm{H}_{2} \mathrm{SO}_{4}$ (Merck), then $0.25 \mathrm{~mL} \mathrm{10 \%} \mathrm{wt/vol} \mathrm{phosphotungstic}$ acid (Sigma Chemical Co) was added and mixed. The mixture was centrifuged at $3000 \mathrm{rpm}$ for 10 minutes, the supernatant was discarded, and the sediment was mixed with $1 \mathrm{~mL} 40 \mathrm{mmol} / \mathrm{L} \mathrm{H}_{2} \mathrm{SO}_{4}$ and 0.15 $\mathrm{mL} \mathrm{10 \%} \mathrm{wt/vol} \mathrm{phosphotungstic} \mathrm{acid.} \mathrm{The} \mathrm{mixture} \mathrm{was} \mathrm{centrifuged} \mathrm{at}$ $3000 \mathrm{rpm}$ for 10 minutes. The sediment was suspended in $2 \mathrm{~mL}$ distilled water, and $0.5 \mathrm{~mL} 0.33 \% \mathrm{wt} / \mathrm{vol}$ thiobarbituric acid reagent (Sigma Chemical Co) was added. The mixture was heated for 60 minutes at $95^{\circ} \mathrm{C}$ in a water bath, then $2.5 \mathrm{~mL} n$-butanol (Sigma Chemical Co) was added and the mixture was vigorously shaken. The butanol layer was taken after centrifugation at $3000 \mathrm{rpm}$ for 15 minutes and absorbance was taken for fluorometric measurement at $553 \mathrm{~nm}$ with $515-\mathrm{nm}$ excitation by Beckman spectrofluorometer. The TBARS concentration was calculated using 1,1,5,5-tetraethoxypropane as standard.

Aortic reactivity study [22]: Rats were dissected, thoracic wall was opened and the thoracic aorta was then clearly dissected, removed and placed in a dish containing Krebs's solution. Under the dissecting microscope, the aorta was thoroughly cleaned from any adhering fat and connective tissue then cut into rings (about $4 \mathrm{~mm}$ long, each). The 
Citation: Kamal SM (2013) Aliskiren Protects against Hypercholesterolemia and Oxidative Stress on Isolated Aortae in Cholesterol-Fed Rats. J Nanomed Nanotechol S5:007. doi:10.4172/2157-7439.S5-007

Page 3 of 5

\begin{tabular}{|c|c|c|c|}
\hline Parameters & Control & $\begin{array}{c}\text { Cholesterol-fed } \\
\text { non-treated }\end{array}$ & $\begin{array}{c}\text { Cholesterol-fed } \\
\text { Aliskiren-treated }\end{array}$ \\
\hline SOD $(\mathrm{IU} / \mathrm{mL})$ & $22 \pm 3.2$ & $0.9 \pm 0.01^{*}$ & $45.3 \pm 5.6^{* *}$ \\
\hline SBP $(\mathrm{mmHg})$ & $100 \pm 5.7$ & $158 \pm 3.4^{\star}$ & $90.5 \pm 3.2^{* \star}$ \\
\hline $\begin{array}{c}\mathrm{TC}(\mathrm{mg} / \mathrm{dL}) \\
\text { relaxation of aortic basal } \\
\text { tone }\end{array}$ & $65.53 \pm 5.43$ & $255.4 \pm 13.22^{*}$ & $45.76 \pm 3.44^{* \star}$ \\
\hline $\begin{array}{c}\text { \% mean relaxation of aortic } \\
\text { basal tone from control } \\
\text { group }\end{array}$ & 66.1412 .16 & $87.43 \pm 6.0^{*}$ & $48.10 \pm 10.23^{\star *}$ \\
\hline $\begin{array}{c}\text { \% mean relaxation of aortic } \\
\text { basal tone from cholesterol- } \\
\text { fed non-treated group }\end{array}$ & & $+32.19 \%$ & $-27.28 \%$ \\
\hline
\end{tabular}

Table 1 showed the results recorded at the end of $12^{\text {th }}$ week therapy by aliskiren regarding SOD enzyme in RBCs lysates, SBP, serum total cholesterol (TC) and relaxation of the isolated aortic ring preparations by $\mathrm{ACh}$. Treatment of cholesterolfed rats group (3) significantly $(p<0.05)$ increased SOD enzyme level, reduced the elevated SBP \& serum total cholesterol (TC) and augmented relaxation responses to ACh compared to cholesterol-fed non-treated group (2). The effects of aliskiren were comparable to those reported with the control group (1)

- * $p<0.05=$ significant decrease in SOD enzyme, while there is a significan increase in mean SBP, serum total cholesterol (TC) and significant reduction in relaxing effect of ACh in cholesterol-fed non-treated group (2) compared to control group (1)

- ${ }^{* *} p<0.05=$ significant increase in SOD enzyme, while significant decrease in mean SBP, serum total cholesterol (TC) and significant augmentation in relaxing effect of ACh in aliskiren-treated group (3) compared to cholesterol-fed nontreated group (2)

Table 1: Mean $\pm S D$ of effect of treatment with aliskiren $(5 \mathrm{mg} / \mathrm{kg} / \mathrm{day}$ ip) on SOD enzyme, SBP, serum total cholesterol (TC) and relaxation of the isolated aortic ring preparations by $\mathrm{ACh}$ in all tested groups.

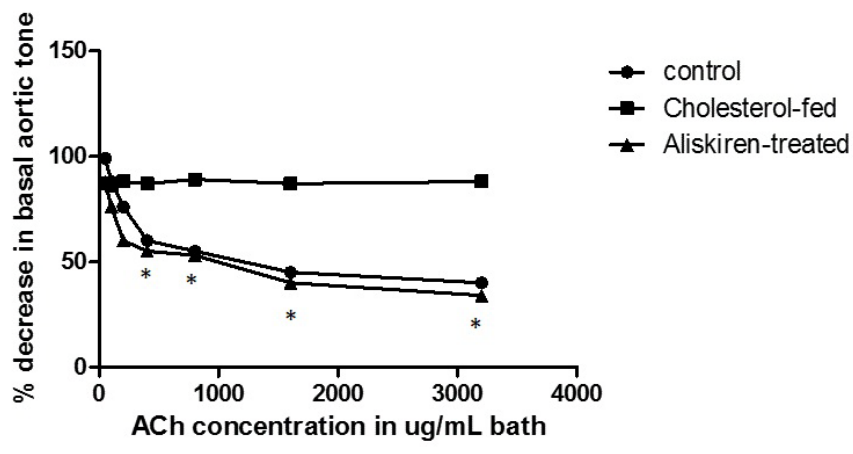

Isolated aortic rings from cholesterol-fed non-treated group showed a significant $(p<0.05)$ decrease in the relaxant effect of acetylcholine $(A C h)$ compared to the control group.

However, aliskiren-treated group significantly $\left({ }^{*} \mathrm{p}<0.05\right)$ augmented relaxation responses to ACh compared to cholesterol-fed non-treated group (2)

Figure 1: shows \% decrease in basal tone of aortic rings isolated from rats of all tested groups.

rings were then carefully suspended at $37^{\circ} \mathrm{C}$ under $2 \mathrm{~g}$ tension in 40 $\mathrm{ml}$ organ baths filled with Krebs' solution of the following composition (mM/L); $\mathrm{NaCl} 118.4, \mathrm{KCl} 4.7, \mathrm{KH} 2 \mathrm{PO} 41.2, \mathrm{MgSO}_{4} 1.2, \mathrm{CaCl} 22.5$, $\mathrm{NaHCO}_{3}$ 25, D-glucose monohydrate 11.1, ascorbic acid 0.022 and EDTA 0.026 . The tissue preparations were gassed continuously with a mixture of $95 \% \mathrm{O} 2$ and $5 \% \mathrm{CO}_{2}$ and left to equilibrate for a period of 90 minutes during which they were repeatedly washed with Krebs' solution. Responses to vasoactive drugs were measured isometrically using a Grass FT O3 force-displacement transducer, and recorded on a polygraph. At the end of the equilibration period, the tissues were contracted by norepinephrine (NE) $(1 \mu \mathrm{g} / \mathrm{mL}$ bath), a concentration known to produce a submaximal contractile response. On top of the plateau response to NE, cumulative concentration-response curves were constructed in response to the relaxant effect of acetylcholine $(\mathrm{ACh})$ in preparations obtained from rats of all groups at range of concentrations $50-3200 \mu \mathrm{g} / \mathrm{mL}$ bath. Relaxation was expressed as a percentage decrease in NE-induced constrictory tone.

Protein determination: The protein content of aortic homogenates was determined by spectrophotometer according to the method of Bradford [23]. The aim is to relate TBARS concentrations as $\mathrm{nmol} /$ mg tissue protein, CAT and GPx enzyme activities as unit/mg tissue protein.

Statistical analysis: Results are expressed as mean \pm SD [Standard Deviation]. Statistical analysis was performed by analysis of variance followed by Tukey's post hoc using GraphPad Prism version 3.00 for Windows 97 (Graph Pad Software, San Diego, CA, U.S.A.). Differences with $\mathrm{p}<0.05$ were considered to be statistically significant.

\section{Results}

Table 1 showed the results recorded at the end of $12^{\text {th }}$ week therapy by aliskiren regarding SOD enzyme in RBCs lysates, SBP, serum total cholesterol (TC) and relaxation of the isolated aortic ring preparations by ACh. Treatment of cholesterol-fed rats group (3) significantly $(\mathrm{p}<0.05)$ increased SOD enzyme level, reduced the elevated SBP and serum total cholesterol (TC) and augmented relaxation responses to ACh compared to cholesterol-fed non-treated group (2). The effects of aliskiren were comparable to those reported with the control group (1).

* $\mathrm{p}<0.05=$ significant decrease in SOD enzyme, while there is a significant increase in mean SBP, serum total cholesterol (TC) and significant reduction in relaxing effect of ACh in cholesterol-fed non-treated group (2) compared to control group (1)

** $\mathrm{p}<0.05=$ significant increase in SOD enzyme, while significant decrease in mean SBP, serum total cholesterol (TC) and significant augmentation in relaxing effect of $\mathrm{ACh}$ in aliskiren-treated group (3) compared to cholesterol-fed nontreated group (2). Figure 1

However, aliskiren-treated group significantly $\left({ }^{*} \mathrm{p}<0.05\right)$ augmented relaxation responses to ACh compared to cholesterol-fed non-treated group (2) (Table 2).

\begin{tabular}{|c|c|c|c|}
\hline & $\begin{array}{c}\text { Control } \\
\text { group }\end{array}$ & $\begin{array}{c}\text { Cholesterol-fed } \\
\text { non-treated group }\end{array}$ & $\begin{array}{c}\text { Cholesterol-fed } \\
\text { aliskiren-treated group }\end{array}$ \\
\hline $\begin{array}{c}\text { Glutathione } \\
\text { peroxidase } \\
\text { Unita/mg tissue } \\
\text { protein }\end{array}$ & $14.22 \pm 2.3$ & $0.34 \pm 0.03^{*}$ & $12.39 \pm 0.34^{* *}$ \\
\hline $\begin{array}{c}\text { Catalase Unit } / \mathrm{mg} \\
\text { tissue protein }\end{array}$ & $63.25 \pm 4.5$ & $2.43 \pm 0.22^{*}$ & $60.55 \pm 3.5^{\star *}$ \\
\hline
\end{tabular}

$\mathrm{a}=\mu \mathrm{g}$ of glutathione consumed per minute.

$\mathrm{b}=$ Moles of hydrogen peroxide consumed per minute.

${ }^{*} p<0.05$, significant reduction in activity of both enzymes in cholesterol-fed nontreated group versus control group.

${ }^{* *} p<0.05$, significant increase in activity of both enzymes by treatment with aliskiren versus cholesterol-fed non-treated group.

A significant $(p<0.05)$ decrease in the activities of these enzymes was demonstrated in cholesterol-fed non-treated rats. Aliskiren-treated group showed a significant ( $p$ $<0.05$ ) increase in their activities compared to cholesterol-fed non-treated group. These findings could support the suggestion that aliskiren, as a DRI, would provide a possible aortic protective effect in cholesterol-fed rats most probably by its antioxidant action.

Table 2: Mean \pm SD changes in the activities of aortic CAT, GPx in rats of all tested groups expressed as unit/mg tissue protein of aortic homogenates. 


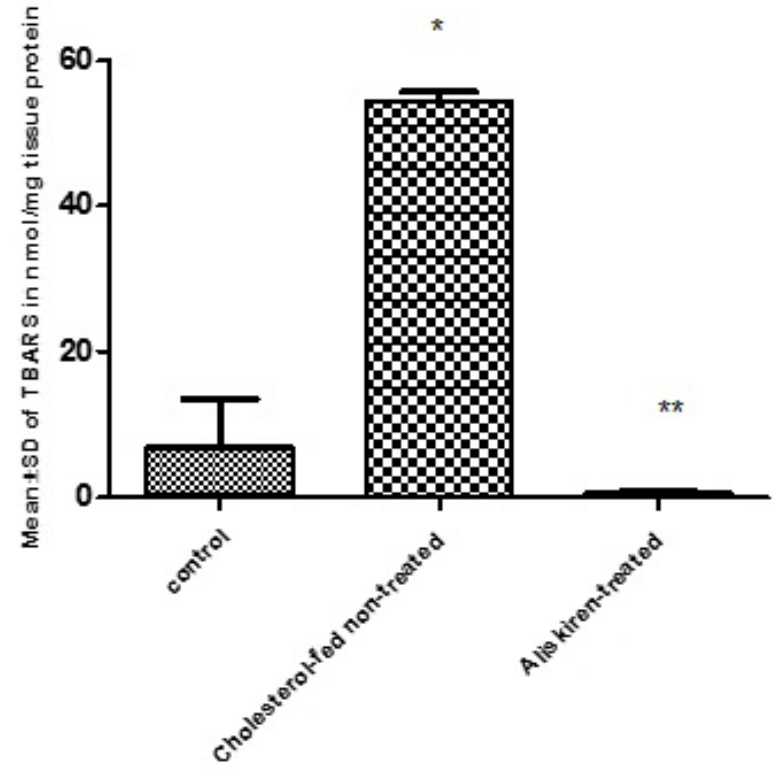

Group

A significant $\left({ }^{*} p<0.05\right)$ decrease in TBARS levels of aliskiren-treated group (3) in comparison to the cholesterol-fed non-treated group (2).

- * $p<0.05=$ significant increase in TBARS levels in group (2) compared to the control group (1)

- ** $\mathrm{p}<0.05=$ significant decrease in TBARS levels in cholesterol-fed aliskirentreated group (3) compared to the cholesterol-fed non-treated rats group (2)

Figure 2: Effect of 12 weeks administration of aliskiren to cholesterol-fed rats on thiobarbituric acid reactive substance (TBARS) in $\mathrm{nmol} / \mathrm{mg}$ tissue protein of the aortic tissue homogenates of rats of all tested groups.

A significant $(\mathrm{p}<0.05)$ decrease in the activities of these enzymes was demonstrated in cholesterol-fed non-treated rats. Aliskirentreated group showed a significant $(\mathrm{p}<0.05)$ increase in their activities compared to cholesterol-fed non-treated group.

These findings could support the suggestion that aliskiren, as a DRI, would provide a possible aortic protective effect in cholesterol-fed rats most probably by its antioxidant action (Figure 2).

\section{Discussion}

The present study showed that aliskiren administration, as a DRI, for 12 weeks ip to cholesterol-fed rats significantly reduced high SBP, serum total cholesterol and augments the relaxing effect of isolated aortic rings from those rats in response to a range of concentrations of ACh. The drug also increased the level of SOD anti-oxidant enzyme in erythrocyte lysates, reduced TBARS contents and increased the activities of CATand GPx enzymes in aortic homogenates compared to cholesterol-fed non-treated group. Interestingly, all these beneficial effects were obtained by aliskiren administration for 12 weeks to cholesterol-fed rats.

Hypercholesterolemia is an important leading factor to serious vascular complications e.g.angina pectoris, acute myocardial infarction and cerebral stroke. The vascular endothelial cells showed serious abnormalities in their functions with a damaging effect that results in disturbance in blood flow and thrombogenic liability [24]. Oxidative stress and a reduction in production of nitric oxide, as a vasodilator marker, result in affection of major arteries as coronaries and renal arteries. Atherosclerosis and deposition of cholesterol in vascular endothelial cells were previously found to be associated with all serious adverse effects of oxidative stress on vessels and vital organs in the body [25].

Oxidative stress associated with high cholesterol diet causes a disturbance in the stabilization of endothelial nitric oxide synthase (NOS) enzyme activity [26] and inhibits endothelial $\mathrm{Ca}^{++}$-dependent potassium channels leading to a marked decrease in the synthesis of endothelial NO which has a vascular protective role [27].

The possible protective effect of aliskiren on aortic tissue against oxidative stress of hypercholesterolemia in cholesterol-fed rats could be based upon its anti-hypertensive effect that is associated with inhibition of renin and hence there is an inhibition of Ang II production and its contributing effect with the damaging effects of ROS on different body's organs and tissues. This explanation could be supported by the ability of aliskiren to increase the level of the powerful anti-oxidant SOD enzyme. This anti-oxidant enzyme plays an important role in the scavenging effect of free radicals and helps in the restoration of normal cellular functions either in the vital organs or blood vessels [28]. It was demonstrated in endothelial NOS knocked-out mice, a protective effect of aliskiren against oxidative damaging effect via the inhibition of oxidative process. It was found that this protective effect was independent to its anti-hypertensive effect as it augments the number and function of pro-angiogenic cells [PAC] in mice that help in preservation of endothelial functions and protect against the development of atherosclerotic plaques on the wall of blood vessels $[29,30]$.

Immunoblotting technique demonstrated that aliskiren induced phosphorylation of ERK1/2 in cardiomyocytes without alterations in expression of $(\mathrm{P}) \mathrm{R}$ or Igf2/M6P receptors. Meanwhile, microarray analysis of the complete genome of aliskiren-treated neonatal-rat cardiomyocytes, with RT-qPCR and immunoblot confirmation assays in rat and human primary cardiomyocytes, revealed that aliskiren upregulated mRNA and increased protein expression of several enzymes that play an important role in cholesterol breakdown [31].

Al-Aubaidy et al. [32] studied the effect of aliskiren on rabbits fed on atherogenic diet that led to marked hypercholesterolemia and advanced atherosclerotic lesion. They proved that aliskiren reduces lipid peroxidation and expression of inflammatory markers in the aorta examined in this study. This study pointed to the beneficial effect of aliskiren, as an anti-atherosclerotic drug, that could be mediated by an inhibition of ang II which is known to be one of the main proatherosclerotic mediators.

Higher doses of aliskiren ( 50 and $100 \mathrm{mg} / \mathrm{kg} /$ day) was administered for 7 days before the administration of a single intraperitoneal injection of doxorubicin (DXR), as a cytotoxic chemotherapy, at a dose of 20 $\mathrm{mg} / \mathrm{kg}$ on day 5 of these 7 days. This chemotherapeutic agent was found to produce a significant increase in malondialdehyde and a significant inhibition in the activity of glutathione in heart tissue, with a significant rise in the serum levels of lactate dehydrogenase (LDH), TC, triglycerides (TG), LDL and reduction in HDL. Fortunately, this pretreatment with aliskiren provides a protection against all these side effects of DXR with strong evidence evidence that aliskiren pretreatment offered a significant cardio-protection against DXR-induced enzymatic changes and cardiac tissue damage [33].

In conclusion, 12 weeks ip administration of aliskiren to cholesterolfed rats showed a significant reduction in mean SBP, serum TC together with a significant improvement in aortic reactivity to ACh. The drug also augmented SOD erythrocytic level, activities of CAT and GPX in 
Citation: Kamal SM (2013) Aliskiren Protects against Hypercholesterolemia and Oxidative Stress on Isolated Aortae in Cholesterol-Fed Rats. J Nanomed Nanotechol S5:007. doi:10.4172/2157-7439.S5-007

aortic homogenates of these tested rats while reduced TBARS aortic content compared to cholesterol-fed rats without drug therapy. These results could point to the aortic protective role of aliskiren, as a DRI, by its possible anti-oxidant effect. This provides a valuable role during its administration to hypertensive-hypercholesterolemic patients with proper control of their blood pressure with aortic protection against oxidative stress.

\section{Acknowledgment}

This research was officially supported by the Medical Research Service of the Ain Shams University. It was financially supported by the laboratory of the Pharmacology Department, Faculty of Medicine, Ain Shams University.

\section{References}

1. Daugherty A, Rateri DL, Lu H, Inagami T, Cassis LA(2004) Hypercholesterolemia stimulates angiotensin peptide synthesis and contributes to atherosclerosis through the AT1A receptor. Circulation 110: 3849-3857.

2. Candido R, Jandeleit-Dahm KA, Cao Z, Nesteroff SP, Burns WC, et al. (2002) Prevention of accelerated atherosclerosis by angiotensin-converting enzyme inhibition in diabetic apolipoprotein E-deficient mice. Circulation 106: 246-253.

3. Hayek T, Kaplan M, Raz A, Keidar S, Coleman R, et al. (2002) Ramipril administration to atherosclerotic mice reduces oxidized low-density lipoprotein uptake by their macrophages and blocks the progression of atherosclerosis. Atherosclerosis 161: 65-74.

4. Ferrario CM (2002) Angiotensin I, angiotensin II and their biologically active peptides. J Hypertens 20: 805-807.

5. Cesari M, Rossi GP, Pessina AC (2002) Biological properties of the angiotensin peptides other than angiotensin II: implications for hypertension and cardiovascular diseases. J Hypertens 20: 793-799.

6. Carey RM, Siragy HM (2003) Newly recognized components of the reninangiotensin system: potential roles in cardiovascular and renal regulation. Endocr Rev 24: 261-271.

7. Ohishi M, Ueda M, Rakugi H, Okamura A, Naruko T, et al. (1997) Upregulation of angiotensin-converting enzyme during the healing process after injury at the site of percutaneous transluminal coronary angioplasty in humans. Circulation 96: 3328-3337.

8. Okamura A, Rakugi H, Ohishi M, Yanagitani Y, Takiuchi S, et al. (1999) Upregulation of renin-angiotensin system during differentiation of monocytes to macrophages. J Hypertens 17: 537-545.

9. Daugherty A, Cassis L (1999) Chronic angiotensin II infusion promotes atherogenesis in low density lipoprotein receptor -/- mice. Ann N Y Acad Sci 892: 108-118.

10. Staessen JA, Li Y, Richart T (2006) Oral renin inhibitors. Lancet 368: 14491456.

11. Getz GS (1990) An overview of atherosclerosis: a look to the future. Toxicol Pathol 18: 623-635.

12. Cassis LA, Rateri DL, Lu H, Daugherty A (2007) Bone marrow transplantation reveals that recipient $\mathrm{AT} 1 \mathrm{a}$ receptors are required to initiate angiotensin IIinduced atherosclerosis and aneurysms. Arterioscler Thromb Vasc Biol 27: 380-386.

13. Bierman EL, Oram J, Mendez A (1991) HDL receptor-mediated cholesterol efflux from cells and its regulation. Adv Exp Med Biol 285: 81-83.

14. Sato J, Mohácsi T, Noel A, Jost C, Gloviczki P, et al. (2000) In vivo gene transfer of endothelial nitric oxide synthase to carotid arteries from hypercholesterolemic rabbits enhances endothelium-dependent relaxations. Stroke 31: 968-975.

15. Miller FJ Jr, Gutterman DD, Rios CD, Heistad DD, Davidson BL (1998) Superoxide production in vascular smooth muscle contributes to oxidative stress and impaired relaxation in atherosclerosis. Circ Res 82: 1298-1305.

16. Aihara Y, Yoshiji H, Noguchi R, Kaji K, Namisaki T, et al. (2013) Direct renin inhibitor, aliskiren, attenuates the progression of non-alcoholic steatohepatitis in the rat model. Hepatol Res 29.

17. Buñag RD (1973) Validation in awake rats of a tail-cuff method for measuring systolic pressure. J Appl Physiol 34: 279-282.
18. Halliwell B, Chirico S (1993) Lipid peroxidation: its mechanism, measurement and significance. Am J Clin Nutr 57: 715S-724S.

19. Sinha AK (1972) Colorimetric assay of catalase. Anal Biochem 47: 389-394.

20. Rotruck JT, Pope AL, Ganther HE, Swanson AB, Hafeman DG, et al. (1973) Selenium: biochemical role as a component of glutathione peroxidase. Science 179: 588-590.

21. Araujo JA, Romano EL, Brito BE, Parthé V, Romano M, et al. (1995) Iron overload augments the development of atherosclerotic lesions in rabbits. Arterioscler Thromb Vasc Biol 15: 1172-1180.

22. Kamal SM, Abdel Razek TT, Hassan GM, Abou Seif AA (2004) Comparison between the effect of bosentan and perindopril on diabetic angiopathy and nephropathy in streptozotocin-induced diabetic rats. J. Egypt. Soc Toxicol 31: 19-28.

23. Bradford MM (1976) A rapid and sensitive method for the quantitation of microgram quantities of protein utilizing the principle of protein-dye binding Anal Biochem 72: 248-254

24. John S, Schmieder RE (2003) Potential mechanisms of impaired endothelia function in arterial hypertension and hypercholesterolemia. Curr Hypertens Rep 5: 199-207.

25. Verbeuren T, Jordaens F, Zonnekeyn L (1986) Effect of hypercholesterolemia on vascular reactivity in the rabbit, I: Endothelium-dependent and endotheliumindependent contractions and relaxations in isolated arteries of control and hypercholesterolemic rabbits. Circ Res 58: 552-564.

26. Scalia R, Appel JZ 3rd, Lefer AM (1998) Leukocyte-endothelium interaction during the early stages of hypercholesterolemia in the rabbit: role of P-selectin ICAM-1, and VCAM-1. Arterioscler Thromb Vasc Biol 18: 1093-1100.

27. Kuhlmann CR, Gast C, Li F, Schäfer M, Tillmanns H, et al. (2004) Cerivastatin activates endothelial calcium-activated potassium channels and thereby modulates endothelial nitric oxide production and cell proliferation. J Am Soc Nephrol 15: 868-875.

28. Fontaine D, Otto A, Fontaine J, Berkenboom G (2003) Prevention of nitrate tolerance by long-term treatment with statins. Cardiovasc Drugs Ther 17: 123128.

29. Yamamoto E, Kataoka K, Dong Y, Nakamura T, Fukuda M, et al. (2009) Aliskiren enhances the protective effects of valsartan against cardiovascular and renal injury in endothelial nitric oxide synthase-deficient mice. Hyperten 54: 633-638.

30. Pöss J, Werner C, Lorenz D, Gensch C, Böhm M, et al. (2010) The renin inhibitor aliskiren upregulates pro-angiogenic cells and reduces atherogenesis in mice. Basic Res Cardiol 105: 725-735.

31. Rodríguez-Penas D, Feijóo-Bandín S, Lear PV, Mosquera-Leal A, García-Rúa $\mathrm{V}$, et al. (2011) Aliskiren affects fatty-acid uptake and lipid-related genes in rodent and human cardiomyocytes. Biochem Pharmacol 82: 491-504.

32. Al-Aubaidy H, Sahib H, Mohammad B, Hadi N, Abas S (2013) Antiatherosclerotic potential of aliskiren: its antioxidant and anti-inflammatory effects in rabbits: a randomized controlled trial. J Pharma Tech Drug Res 2:11.

33. Rashikh A, Pillai KK, Ahmad SJ, Akhtar M, Najmi AK (2013) Aliskiren alleviates doxorubicin-induced nephrotoxicity by inhibiting oxidative stress and podocyte injury. J Renin Angiotensin Aldosterone Syst 14: 14-22.

This article was originally published in a special issue, Nanotechnology: Challenges \& Perspectives in Medicine handled by Editor(s). Dr. Malavosklish Bikram, University of Houston, USA 